\title{
A Proteomic Perspective on the Bacterial Adaptation to Cold: Integrating OMICs Data of the Psychrotrophic Bacterium Exiguobacterium antarcticum B7
}

\author{
Rafael A. Baraúna *, Dhara Y. Freitas, Juliana C. Pinheiro, Adriana R. C. Folador and Artur Silva \\ Laboratory of Genomics and Bioinformatics, Center of Genomics and Systems Biology, \\ Institute of Biological Sciences, Federal University of Pará, Belém 66075-110, Brazil; dharayf@gmail.com (D.Y.F.); \\ julianacrz24@gmail.com (J.C.P.); carneiroar@gmail.com (A.R.C.F.); asilva@ufpa.br (A.S.) \\ * Correspondence: rabarauna@ufpa.br; Tel.: +51-91-3201-7000 \\ Academic Editors: Jens R. Coorssen, Alfred L. Yergey and Jacek R. Wisniewski \\ Received: 30 September 2016; Accepted: 5 December 2016; Published: 23 February 2017
}

\begin{abstract}
Since the publication of one of the first studies using 2D gel electrophoresis by Patrick H. O'Farrell in 1975, several other studies have used that method to evaluate cellular responses to different physicochemical variations. In environmental microbiology, bacterial adaptation to cold environments is a "hot topic" because of its application in biotechnological processes. As in other fields, gel-based and gel-free proteomic methods have been used to determine the molecular mechanisms of adaptation to cold of several psychrotrophic and psychrophilic bacterial species. In this review, we aim to describe and discuss these main molecular mechanisms of cold adaptation, referencing proteomic studies that have made significant contributions to our current knowledge in the area. Furthermore, we use Exiguobacterium antarcticum B7 as a model organism to present the importance of integrating genomic, transcriptomic, and proteomic data. This species has been isolated in Antarctica and previously studied at all three omic levels. The integration of these data permitted more robust conclusions about the mechanisms of bacterial adaptation to cold.
\end{abstract}

Keywords: genomic; transcriptomic; proteomic; Exiguobacterium antarcticum B7; 2DE

\section{Introduction}

One of the first omic studies performed and published was the 2D gel electrophoresis (2DE) of Escherichia coli cultures by Patrick H. O'Farrell in 1975 [1]. Thirteen years later, the development of two ion sources for mass spectrometry-matrix-assisted laser desorption/ionization (MALDI) and electrospray ionization (ESI) - allowed the identification of proteins extracted from 2DE spots [2,3]. Many years later, the development of next-generation sequencing (NGS) elevated the importance of omics sciences and led to the preparation of an essential database of gene sequences to assist proteomic approaches. Several studies in the environmental microbiology field have used 2DE and other proteomic techniques to answer questions about microbial adaptation to different environmental variables. In this context, bacterial adaptation to cold environments is a "hot topic" because of its application in biotechnological processes.

Several microorganisms have the ability to tolerate extreme environmental conditions, which may be essential for their survival [4]. Antarctica is one of the most extreme environments on the planet, and microbial habitats in this region include marine waters, air, snow, glacial ice, surface soils, and permafrost. Psychrophilic and psychrotrophic organisms that inhabit this polar region are constantly exposed to variations in temperature, desiccation, high or low levels of salinity or 
$\mathrm{pH}$, prolonged periods in the absence of light during the winter, and high levels of ultraviolet (UV) radiation.

To cope with those environmental stresses and to survive and grow in low-temperature environments, those microorganisms exhibit several mechanisms of physiological adaptation, which are not ubiquitous in other bacteria. These mechanisms include (i) the increased fluidity of cell membranes; (ii) a reduced freezing point of the aqueous phase of the cytoplasm and stabilization of macromolecules; (iii) cellular responses to temperature decreases through cold shock and cold acclimation proteins (CSPs and CAPs, respectively); (iv) protection against reactive oxygen species (ROS) through catalases, peroxidases, superoxide dismutase, and oxidoreductases; (v) and the maintenance of catalytic efficiency in the cold [5].

The genus Exiguobacterium comprises species that have been isolated from several habitats with a wide temperature range (from $-12{ }^{\circ} \mathrm{C}$ to $55^{\circ} \mathrm{C}$ ) including glacial ice, hot springs, the rhizosphere of plants, Siberian permafrost, and tropical and temperate soils [6]. This genus harbors psychrotrophic, mesophilic, and moderate thermophilic species and strains with biotechnological, industrial, bioremediation, and agricultural properties of interest [7]. Currently, there are four species of this genus whose genomes are completely sequenced including Exiguobacterium antarcticum B7 and draft genome sequences for other Exiguobacterium strains [8-11].

Recent works using E. antarcticum B7 demonstrated the importance of combining different molecular approaches to better understand bacterial adaptation to cold [12-14]. System biology analyses using the transcriptome data of E. antarcticum B7 identified a potential change in the metabolic pathway of fatty acids in response to cold [13]. Thus, genomic, transcriptomic, proteomic, and other omic technologies generate a large quantity of data that can be used and integrated to better formulate hypotheses about the mechanisms of microbial adaptation.

In this review, we aim to describe and discuss the main molecular modifications that occur in bacterial cells when exposed to low temperatures and the importance of omics technologies in this field. Furthermore, we use Exiguobacterium antarcticum B7 as a model organism to present the importance of integrating genomic, transcriptomic, and proteomic data to allow more robust conclusions about the mechanisms of bacterial adaptation to cold.

\section{Mechanisms of Bacterial Adaptation to Cold}

\subsection{Chemical Modification of the Cellular Membrane}

The cell membrane of prokaryotes becomes more rigid in low temperatures, and some chemical changes occur in the membrane fatty acids to prevent cellular damage. New lipid molecules are synthesized or modified to produce lipids with a low gel-liquid crystalline phase transition to maintain membrane fluidity [15]. The main changes observed in the membrane fatty acids include an increase in the number of unsaturations and methyl groups, a decrease in the chain length, and an increased rate of anteiso chemical ramifications compared to the iso ramifications [15]. This process of membrane adaptation is commonly termed homeoviscous adaptation [16]. Polyunsaturated fatty acids (PUFAs) have a much lower melting temperature compared to monounsaturated fatty acids. Thus, PUFAs are responsible to maintain membrane fluidity even in temperatures below $0{ }^{\circ} \mathrm{C}$. The unsaturated branched-chain fatty acids are generated by anaerobic (de novo synthesis) or aerobic pathways (post-synthesis modification) [15].

An anaerobic pathway is commonly found in Gram-positive bacteria of the Bacillales order, where unsaturated branched-chain fatty acids are synthesized from simpler molecules such as acetyl-CoA [17]. First, acetyl-CoA is converted to malonyl-CoA by acetyl-CoA caboxylase and subsequently linked to an acyl carrier protein (ACP), forming malonyl-ACP. This molecule undergoes successive rounds of elongation of its fatty acid chain through a cyclic pathway whose reactions are catalyzed by enzymes encoded by the genes $f a b F, f a b G, f a b I$, and $f a b H$. The newly synthesized fatty acid molecule is then 
linked to glycerol-3-phosphate to form phosphatidic acid, which is a key intermediate molecule of all membrane glycerolipids [17].

In the aerobic pathway, the unsaturations are introduced directly into the membrane phospholipids by desaturase enzymes through dehydrogenation reactions. In Bacillus subtilis, the expression of $\Delta 5$-fatty acid desaturase is activated by a two-component system called DesR-DesK [18]. It has been suggested that a change in membrane fluidity caused by low temperatures result in conformational changes in DesK, triggering autokinase activity [19]. Once activated, DesK phosphorylates DesR, which binds to DNA, inducing the expression of desaturase genes [20,21].

Omic studies have allowed a better understanding of the microbial cold adaptation mechanisms through the identification of differentially expressed proteins. In a genomic study of Colwellia psychrerytharea the proteins involved in the synthesis, ramification, and cis-isomerization of polyunsaturated fatty acids were described [22]. Subsequently, the authors identified differentially expressed genes of polyunsaturated fatty acid synthases ( $p f a C, p f a A$, and $p f a D$ ) [23]. To date, these synthase enzymes have been described only in marine bacteria [23,24]. In Sphingopyxis alaskensis, the enzymes involved in the de novo synthesis of fatty acids were described using quantitative proteomic approaches [25]. However, it was not possible to determine whether the bacterium produces new fatty acid chains or desaturates the existing membrane lipids. Recent studies have shown that two psychrotrophic species-Exiguobacterium sibiricum 255-15 and Psychrobacter arcticus 273-4-repress the expression of their genes associated with fatty acid biosynthesis while upregulating the genes associated with desaturation at low temperatures $[9,26]$.

Interestingly, E. sibiricum 255-15 exhibited an increase in the expression of genes involved in peptidoglycan biosynthesis. An increase in cell wall density can protect bacteria against cell disruption that may be caused by ice formation and osmotic pressure at low temperatures [9]. The same behavior was observed in Planococcus halocryophilus Or1 [27]. In contrast, other studies have demonstrated that the species $P$. arcticus represses the expression of genes involved in peptidoglycan biosynthesis and enhances the expression of genes involved in the autolytic cleavage of the cell wall [26]. In Sphingopyxis alaskensis, a high abundance of proteins involved in cell wall biogenesis was described at $10{ }^{\circ} \mathrm{C}$ including a membrane structural lipoprotein OmpA which acts in the optimization of the structure and function of the membrane [25]. Recently, a transcriptomic analysis of Listeria monocytogenes cultivated under low temperatures and osmotic stress revealed the upregulation of genes associated with the biosynthesis of peptidoglycan and fatty acid molecules [28].

It is also important to note that the activity of membrane carriers is directly influenced by the lipidic state of the membrane [29]. The transport and diffusion through the membrane are also compromised at low temperatures. To balance this deficit, proteins of the transport system are upregulated. Despite the different mechanisms observed in the Bacteria domain, the molecular modifications at low temperatures have one single purpose: increase the number of membrane polyunsaturated branched-chain fatty acids to maintain membrane fluidity and the correct transport and diffusion of substances through this important biological barrier.

\subsection{Cold-Adapted Enzymes}

Microbial adaptation to extreme temperatures requires the evolution of enzymes to work with a high catalytic efficiency under these extreme conditions. Such extremophilic enzymes are valuable tools for studying the relationships between protein stability, dynamics, and function [30]. Low temperatures markedly reduce the $k_{\text {cat }}$ of nearly all enzymatic reactions in a cell [31]. However, because this may not seem to be a significant barrier to microbial physiological processes, it is very clear that psychrophilic and psychrotrophic enzymes have adapted to efficiently operate at low temperatures. This enzymatic efficiency depends on the ratio between $\mathrm{K}_{\mathrm{cat}} / \mathrm{K}_{\mathrm{m}}$. $\mathrm{K}_{\mathrm{cat}}$ measures how many substrate molecules are converted in products in a unit of time under optimal catalytic conditions. The $\mathrm{K}_{\text {cat }}$ constant is commonly called the "turnover number." The constant $\mathrm{K}_{\mathrm{m}}$ measures the substrate concentration that drives the reaction to half of its maximum velocity. 
A high value of $\mathrm{K}_{\text {cat }}$ (fast turnover) and a low value of $\mathrm{K}_{\mathrm{m}}$ (high affinity for a given substrate) increase the enzymatic efficiency. This enzymatic efficiency is directly dependent on the conformational dynamics of the enzyme. Using proteomic, molecular modeling, X-ray crystallography, and Nuclear Magnetic Resonance (NMR), it was observed that a low level of conformational stability allows cold-adapted enzymes to have high rates of enzymatic turnover at low temperatures [5,32,33]. These analyses led to the concept of "flexibility", which describes the capacity of an enzyme to exhibit increased catalytic activity due to the loss of conformational stability. High flexibility occurs as a result of a reduction in the number of chemical interactions between the amino acids of the protein. This low molecular rigidity allows better complementarity between the active site and the substrate at a low energy cost. Many chemical factors of the enzyme contribute to increased catalysis in cold, including a decrease in the hydrophobicity of the protein core, a decrease in the number of aliphatic amino acids and protein residues forming salt bridges, and increased entropy. Not all of these characteristics are present in the same cold-adapted enzyme, but this list represents some of the changes observed by comparing psychrophilic enzymes to their mesophilic counterparts [34,35].

Amino acid composition seems to be an important characteristic to cold adaptation in several microorganisms. An $\alpha$-amilase from the psychrophilic ciliated protozoon Euplotes focardii showed large modifications in amino acid composition when compared to an $\alpha$-amilase of the mesophilic congeneric species Euplotes crassus. This modification consequently alters the types of intramolecular and surface chemical bonds [36]. Psychrophilic enzyme of E. focardii avoided charged, aromatic, and hydrophobic residues on its surface [36]. The genome of Psychrobacter arcticus 273-4 shows a statistically significant modification of amino acid composition compared to the mesophilic microorganisms, which can facilitate the flexibility of the proteins at low temperatures and consequently maintain cell viability in cold habitats [35]. Another example of altered amino acid composition is described in the genus Vibrionaceae. The psychrophilic species of the genus have proteins with a reduced number of proline residues [37]. Proline decreases the flexibility of the protein due to the rigidity of its nitrogen-carbon bond [38]. Thus, proline substitution in psychrophilic proteins increases flexibility of the molecule and consequently decreases the energy required to interact with the substrate. Arginine is also considered an amino acid that promotes structural rigidity since it forms salt bridges and hydrogen bonds with side chains of the protein structure [39]. A low amount of arginine has been observed in a thermolysin of the psychrophilic Antarctic bacterium [39].

\subsection{Cold Shock and Cold Acclimation Proteins}

One of the most prominent responses of microorganisms to cold environments is the expression of cold shock or cold acclimation proteins. It is important to note that psychrophilic and psychrotrophic as well as mesophilic and thermophilic microorganisms express cold shock proteins to neutralize the effects of temperature reduction. A cold shock response occurs when the microorganism is transferred from an optimal growth temperature to a cold temperature, triggering an immediate and transient molecular response. However, the acclimation process occurs when the bacteria remain exposed to cold for a long period, leading to a late and continuous molecular response [40]. CSPs are expressed by homologous genes that exhibit RNA chaperone activity and thus act to destabilize secondary structures of RNA erroneously formed due to exposure to cold. The activity of these proteins maintains the correct flux of the transcription and translation process in prokaryotes [41].

The first bacterial cold shock protein reported was CspA of Escherichia coli [42]. Subsequently, several other CSPs were described in a large range of Gram-positive and Gram-negative bacteria. In E. coli, cold shock proteins can be divided into two major groups: I and II. CSPs belonging to group I (CspA, CspB, CspG, CspI, CsdA, RbfA, NusA, and PNPase) are drastically induced at low temperatures compared to the CSPs of group II (RecA, IF-2, H-NS, GyrA, Hsc66, and HscB). CspA, CspB, CspG, and CspI act as RNA chaperones [41]. After cold shock, the expression of CSPs of group I is dramatically decreased while other proteins are expressed during the acclimation phase to maintain cell function. CsdA is a DEAD-box RNA helicase that increases septation, resulting in the formation of coccobacilli 
shape at low temperatures [43]. CsdA also acts as a RNA chaperone [43]. RbfA is a ribosome binding factor that is involved in ribosome maturation at cold temperatures [44]. Finally, PNPase is an enzyme that catalyzes the phosphorolysis of single-stranded polyribonucleotides and is the major factor responsible for the reduction of CSPs in bacterial cells after cold shock response [45].

Currently, several studies have reported other molecular functions of CSP homologues such as osmotic balance, protection to oxidative stress, starvation, and other types of stress, showing that this protein family has a greater importance than previously thought to the process of microbial adaptation to extreme conditions [46].

\subsection{Other Important Aspects}

In addition to the mechanisms of cold adaptation mentioned above, the production of carotenoids markedly contributes to bacterial survival in cold environments. Carotenoids are tetraterpenoids, pigments found naturally occurring in microorganisms, plants, and even animals. Carotenoids are synthesized by several species of bacteria, algae, and fungi in response to several environment stresses [47]. Prokaryotic organisms that produce carotenoids have been summarized by Takano and colleagues [48]. However, since 2006 several carotenoid-producing bacterial species were discovered in cold environments [49]. Carotenoids are detected in the membrane of psychrophilic [49], psychrotrophic [27], and mesophilic [50] bacterial species. The high frequency of pigment production in strains isolated from cold environments suggests that these pigments play an important role in the adaptation to this ecological niche [51]. At low temperatures, the production of polar carotenoids suppresses the production of non-polar carotenoids. This chemical modification was observed in Arthrobacter agilis, Sphingobacterium antarcticus, and Micrococcus roseus [50,52,53].

In addition, carotenoids protect free-living bacteria from high levels of UV radiation and promote resistance to cellular oxidative stress [49]. Several genes involved in carotenoid biosynthesis, such as $i d i, c r t E, \operatorname{crt} B, \operatorname{crtI}, \operatorname{crtEB}, \operatorname{crt} Y e$, and $\operatorname{crt} Y f$, were described in bacterial species of the Arthrobacter genus isolated from Antarctic soils [49]. Recently, the Prokaryotic Carotenoid Database (ProCarDB) was created by using 304 unique carotenoids synthesized through 50 biosynthetic pathways distributed in 611 prokaryotes [54].

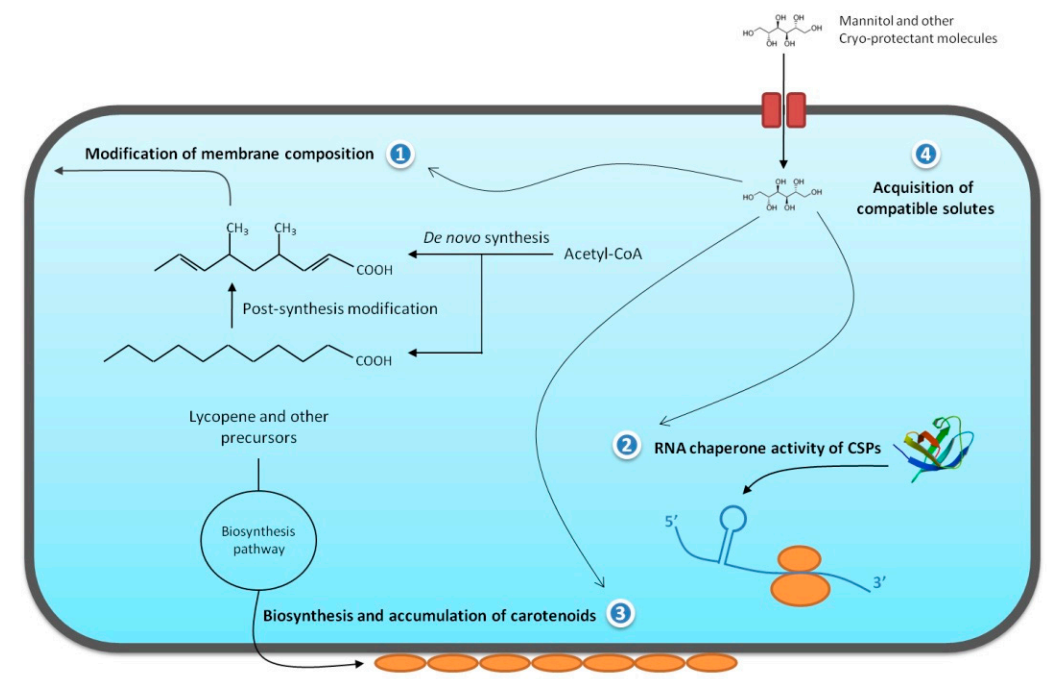

Figure 1. Representation of the main molecular modifications presented by bacterial cells during cold adaptation. Four adaptations are presented: (1) production of unsaturated branched-chain fatty acids to maintain membrane fluidity; (2) destabilization of adverse RNA structures by cold shock proteins; (3) production of carotenoids to assist in the maintenance of membrane fluidity and prevent cell damage by UV radiation; and (4) transport of compatible solutes such as mannitol to stabilize the cytoplasmic environment and prevent ice formation. 
Additionally, thermal stress affects the osmotic balance of the microbial cell, resulting in a large efflux of cytoplasmatic water. Therefore, to prevent water loss and intracellular ice formation, bacterial cells accumulate compatible solutes in the cell cytoplasm. Examples of such cryo-protectant molecules are glucose, trehalose, glycogen, fructose, alanine, betaine, mannitol, and glycerol. These substances also prevent protein aggregation by stabilizing cytoplasmic macromolecules [55]. Figure 1 summarizes the main molecular modifications that occur in bacterial cells adapted to low temperatures, as described above.

\section{Exiguobacterium antarcticum B7 as a Model Organism for Studies of Cold Adaptation}

Exiguobacterium antarcticum B7 is a psychrotrophic bacterium isolated from a biofilm formed in the sediment of Lake Ginger, Antarctic Peninsula [8]. Its optimal growth temperature is $37^{\circ} \mathrm{C}$, and its minimal growth temperature is $-2{ }^{\circ} \mathrm{C}$. E. antarcticum $\mathrm{B} 7$ has bacillary morphology that may change depending on the physicochemical conditions of the environment. Its genome was sequenced using NGS, and its gene expression at low temperatures was evaluated using transcriptomic and proteomic techniques [14]. Figure 2 summarizes the omic analyses performed and shows the methods and results obtained. In this approach, genomic analysis is the starting point for generating a large quantity of data that is subsequently used as the basis for the validation of experimental models through transcriptomics and proteomics (Figure 2). Subsequently, the data set generated by these high-throughput methods can be used in top-down models of systems biology, as discussed and proposed by Bernhard Palsson [56] after the emergence of the first NGS technologies in 2002. Recently, the metabolic pathway for the de novo biosynthesis of fatty acids in E. antarcticum B7 was reconstructed using constraint-based approaches [13]. Applying the $\log _{2} \mathrm{FC}$ (log base 2 Fold Change) of the transcriptome in the calculated model, the fluxome was modified and the metabolic pathway of E. antarcticum B7 started to produce short-chain fatty acids. This metabolic behavior has been experimentally documented for other cold-adapted bacteria $[23,25]$.

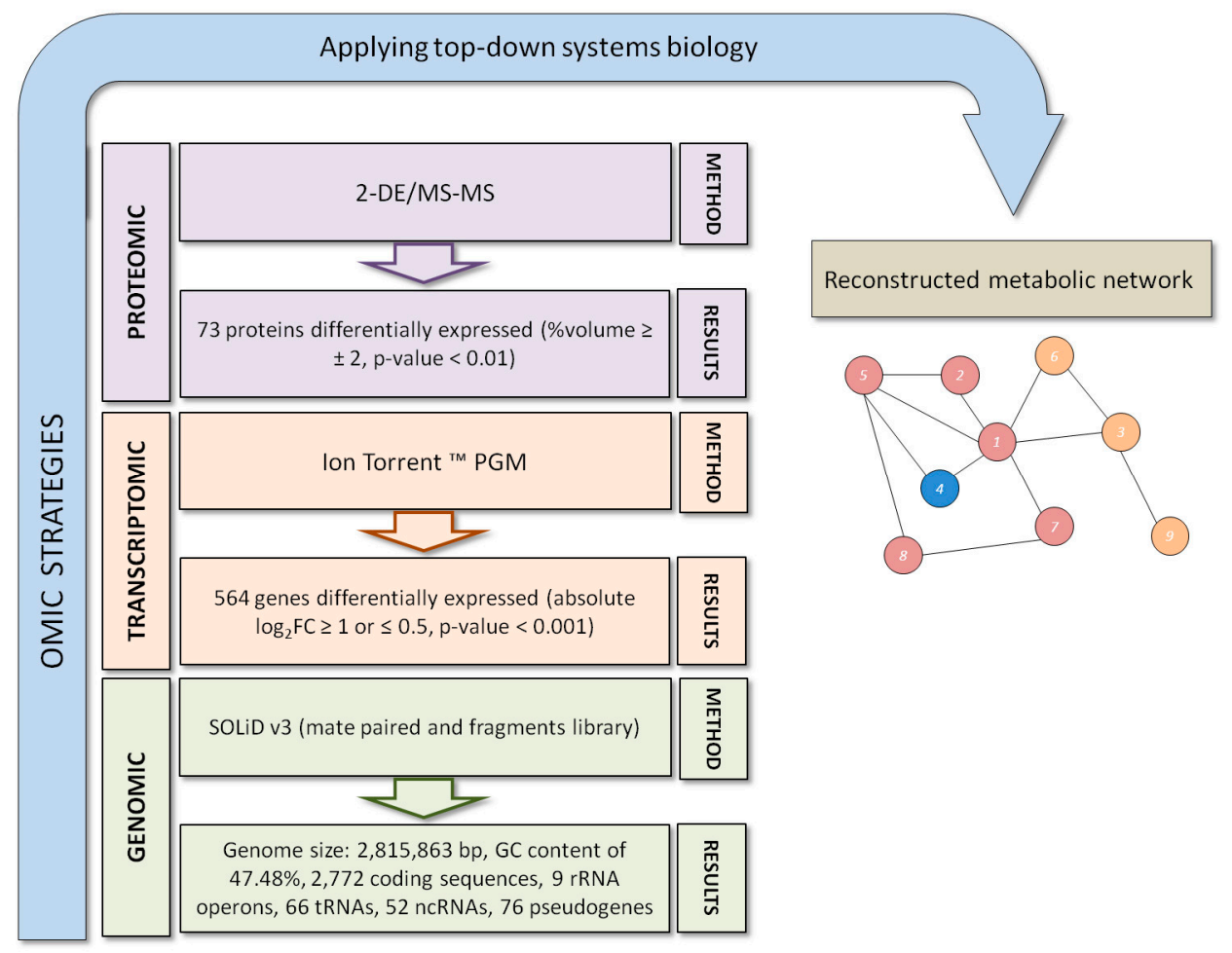

Figure 2. Flowchart showing the omics strategies used to study cold adaptation of E. antarcticum B7. Each omic analysis contains the method used and the results achieved. This large amount of data can then be used to reconstruct metabolic models using top-down approaches of systems biology. 
A total of 564 genes of E. antarcticum B7 were differentially expressed in cold. Gel-based proteomic analyses described 73 differentially expressed proteins [14]. Genes of E. antarcticum B7 that are involved in the five adaptive pathways described above are listed in Table 1. Interestingly, two cold shock proteins were downregulated in the cold (Csp5 and Csp6) (Table 1). These two proteins were not detected in the proteomic analysis. However, the other four CSPs were upregulated at $0{ }^{\circ} \mathrm{C}$, and the proteomic results showed that Csp1 was 32-fold more expressed at low temperatures [14]. Thus, Csp1 is the main CPS of E. antarcticum B7. Additionally, Csp1 was detected in four different spots of the gel, two of which presented an interesting pattern of pI modification. These two spots have the same molecular weight and different pI values (Figure A1 in Appendix A). The results suggest a possible post-translational modification of CPSs at low temperatures such as phosphorylation. One of these proteoforms of Csp1 (spot 884) apparently appears only at $0^{\circ} \mathrm{C}$ (Figure A1 in Appendix A).

Table 1. E. antarcticum B7 genes involved in metabolic pathways of cold adaptation. Next to the name of the genes are the $\log _{2} \mathrm{FC}$ values and $p$-values of the transcriptome assays published by Dall'Agnol and colleagues [40]. Pseudogenes are identified in parentheses.

\begin{tabular}{|c|c|c|c|c|c|}
\hline Genes & $\log _{2} \mathrm{FC}$ & $p$-Value & Genes & $\log _{2} \mathrm{FC}$ & $p$-Value \\
\hline \multicolumn{3}{|c|}{ Cold shock proteins } & \multicolumn{3}{|c|}{ De novo synthesis of fatty acids } \\
\hline $\operatorname{csp} 1$ & 1.94 & 0 & $\operatorname{acc} A$ & 0.45 & 0.01 \\
\hline $\operatorname{csp} 2$ & 2.16 & $5.43 \times 10^{-194}$ & $a c c B$ & -0.05 & 0.01 \\
\hline $\operatorname{csp} 3$ & 2.30 & 0 & $\operatorname{accC}$ & -0.56 & $5.68 \times 10^{-27}$ \\
\hline $\operatorname{csp} 4$ & 2.46 & 0 & $a c c D$ & -0.28 & $7.55 \times 10^{-4}$ \\
\hline $\operatorname{csp} 5$ & -1.06 & $3.73 \times 10^{-35}$ & fapR & 0.58 & $4.80 \times 10^{-21}$ \\
\hline $\operatorname{csp} 6$ & -1.28 & $4.41 \times 10^{-194}$ & pls $X$ & 0.77 & $2.31 \times 10^{-46}$ \\
\hline \multicolumn{3}{|c|}{ Desaturation of membrane fatty acids } & $f a b D$ & 0.94 & $2.92 \times 10^{-85}$ \\
\hline $\operatorname{des} K$ & 7.03 & $8.15 \times 10^{-16}$ & $f a b G$ & 0.85 & $8.42 \times 10^{-63}$ \\
\hline $\operatorname{des} R$ & -0.48 & $9.37 \times 10^{-8}$ & fabH1 & 0.85 & $2.67 \times 10^{-26}$ \\
\hline \multicolumn{3}{|c|}{ Transport of compatible solutes } & $f a b F$ & 0.69 & $3.46 \times 10^{-16}$ \\
\hline ориCA & 3.17 & $1.99 \times 10^{-62}$ & $f a b I$ & -1.74 & 0 \\
\hline ориСС & 1.61 & $3.06 \times 10^{-29}$ & $\mathrm{plsC}$ & -0.82 & $1.28 \times 10^{-6}$ \\
\hline opuE & 3.70 & $4.26 \times 10^{-16}$ & \multicolumn{3}{|c|}{ Carotenoid biosynthesis } \\
\hline opuCD & -2.72 & $8.67 \times 10^{-24}$ & crtI (pseudo) & 3.94 & $4.65 \times 10^{-43}$ \\
\hline \multirow[t]{2}{*}{ ориBA } & -0.52 & $6.11 \times 10^{-4}$ & yisP1 (pseudo) & -1.33 & $3.09 \times 10^{-41}$ \\
\hline & & & yisP2 & 0.75 & $2.16 \times 10^{-7}$ \\
\hline
\end{tabular}

Clearly, transcriptomic allowed a more embracing analysis of gene expression in E. antarcticum when compared to other omic approaches. However, transcriptomics has analytical limitations such as multi-mapping reads which may cause bias in the calculation of gene expression for homologous genes such as $\operatorname{csp}$ [57]. In this case, proteomics allowed the identification of the main CSP used by E. antarcticum during cold response. The other proteins identified belong to metabolic pathways commonly described in gel-based proteomic analyzes such as oxidative stress, heat shock proteins, and cellular respiration [58]. Those findings such as genomic signature, gene expression pattern, CSP proteoform identification, and reconstruction of metabolic networks, could only be achieved by using all levels of omic analyses, which emphasizes the need to integrate the data of these high throughput methods.

\section{Conclusions and Future Perspectives}

By observing the different metabolic behavior described in this review, it can be noted that different psychrotrophic and psychrophilic species have ecologically converged to adapt to low-temperature environments via different biological methods. Different proteomic and other omic approaches were 
used to achieve our current knowledge on microbial adaptation to cold. The ecological relationships between microorganisms living in cold environments have also been analyzed by metaproteomics [59].

The most recent proteomic methods based on liquid chromatography coupled with mass spectrometry (LC-MS/MS) can generate a large amount of data that can assist us in understanding important aspects of bacterial adaptation to cold. Methods such as selected reaction monitoring (SRM) in targeted-MS proteomic are now being used in the field of microbiology [60]. SRM is better applied to microorganisms that have been previously analyzed using high-throughput techniques.

Genomics has now reached a high level of sensitivity, precision, and accuracy in their analyses. Consequently, transcriptomics and proteomics methods have tended to evolve to generate large quantities of data with increased reliability. Rapid technological evolution has led to the development of sub-omic areas that will permit the analyses of microbial adaptation to different environments through a holistic perspective (e.g., surfomics is based on methods for rapid identification of cell surface proteins) [61]. Finally, bioinformatics is a strategic area for the development and biotechnological application of omics sciences, especially proteomics.

Acknowledgments: The authors are thankful to the Brazilian agencies Conselho Nacional de Desenvolvimento Científico e Tecnológico (CNPq) and Coordenação de Aperfeiçoamento de Pessoal de Nível Superior (CAPES).

Author Contributions: R.A.B. designed the article structure and wrote, edited, and reviewed the final version. D.Y.F., J.P., A.R.C.F., and A.S. also wrote some of the article's sections.

Conflicts of Interest: The authors declare no conflict of interest.

\section{Appendix A}

(a)

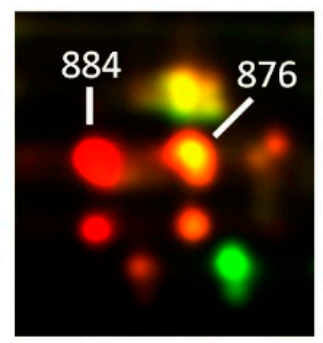

Red spots $=\mathrm{Cy} 5\left(0^{\circ} \mathrm{C}\right)$ Green spots $=\mathrm{Cy} 3\left(37^{\circ} \mathrm{C}\right)$ (b) 876

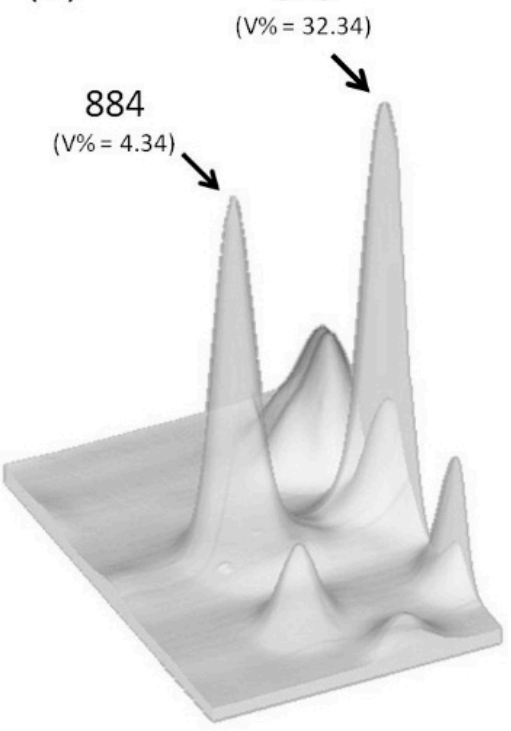

Figure A1. (a) Fraction of a Differential Gel Electrophoresis (DIGE) comparing the proteome of E. antarcticum grown at $37{ }^{\circ} \mathrm{C}$ (green spots) and $0{ }^{\circ} \mathrm{C}$ (red spots). Each spot is indicated by its ID;

(b) Three-dimensional view of the spots with their respective values of volume percentage.

\section{References}

1. O'Farrell, P.H. High resolution two-dimensional electrophoresis of protein. J. Biol. Chem. 1975, 250, 4007-4021. [PubMed]

2. Tanaka, K.; Waki, H.; Ido, Y.; Akita, S.; Yoshikazu, Y.; Yoshida, Y.; Matsuo, T. Protein and polymer analyses up to $m / z$ 100,000 by laser ionization time-of-flight mass spectrometry. Rapid Commun. Mass Spectrom. 1988, 2, 151-153. [CrossRef] 
3. Fenn, J.B.; Mann, M.; Meng, C.K.; Wong, S.F. Electrospray ionization for mass spectrometry of large biomolecules. Science 1989, 246, 64-71. [CrossRef] [PubMed]

4. Rampelotto, P.H. Resistance of microorganisms to extreme environmental conditions and its contribution to astrobiology. Sustainability 2010, 2, 1602-1623. [CrossRef]

5. Casanueva, A.; Tuffin, M.; Cary, C.; Cowan, D.A. Molecular adaptations to psychrophily: The impact of "omic" technologies. Trends Microbiol. 2010, 18, 374-381. [CrossRef] [PubMed]

6. Rodrigues, D.F.; Tiedje, J.M. Multi-locus real-time PCR for quantitation of bacteria in the environment reveals Exiguobacterium to be prevalent in permafrost. FEMS Microbiol. Ecol. 2007, 59, 489-499. [CrossRef] [PubMed]

7. Vishnivetskaya, T.A.; Kathariou, S.; Tiedje, J.M. The Exiguobacterium genus: Biodiversity and biogeography. Extremophiles 2009, 13, 541-555. [CrossRef] [PubMed]

8. Carneiro, A.R.; Ramos, R.T.J.; Dall'Agnol, H.; Pinto, A.C.; Soares, S.C.; Santos, A.R.; Guimarães, L.C.; Almeida, S.S.; Baraúna, R.A.; Graças, D.A.; et al. Genome sequence of Exiguobacterium antarcticum B7, isolated from a biofilm in Ginger Lake, King George Island, Antarctica. J. Bacteriol. 2012, 194, 6689-6690. [CrossRef] [PubMed]

9. Rodrigues, D.F.; Ivanova, N.; He, Z.; Huebner, M.; Zhou, J.; Tiedje, J.M. Architecture of thermal adaptation in an Exiguobacterium sibiricum strain isolated from 3 million year old permafrost: A genome and transcriptome approach. BMC Genom. 2008, 9, 547. [CrossRef] [PubMed]

10. Vishnivetskaya, T.A.; Lucas, S.; Copeland, A.; Lapidus, A.; del Rio, T.G.; Dalin, E.; Tice, H.; Bruce, D.C.; Goodwin, L.A.; Pitluk, S.; et al. Complete genome sequence of the thermophilic Exiguobacterium sp. AT1b. J. Bacteriol. 2011, 193, 2880-2881. [CrossRef] [PubMed]

11. Tang, J.; Zhang, Y.; Meng, H.; Xue, Z.; Ma, J. Complete genome sequence of Exiguobacterium sp. strain MH3, isolated from rhizosphere of Lemma minor. Genome Announc. 2013, 1, 2012-2013. [CrossRef] [PubMed]

12. Baraúna, R.A.; das Graças, D.A.; Nunes, C.I.P.; Schneider, M.P.C.; Silva, A.; Carepo, M.S.P. De novo synthesis of fatty acids is regulated by FapR protein in Exiguobacterium antarcticum B7, a psychrotrophic bacterium isolated from Antarctica. BMC Res. Notes 2016, 9, 447. [CrossRef] [PubMed]

13. Kawasaki, R.; Baraúna, R.A.; Silva, A.; Carepo, M.S.P.; Oliveira, R.; Marques, R.; Ramos, R.T.J.; Schneider, M.P.C. Reconstruction of the fatty acid biosynthetic pathway of Exiguobacterium antarcticum B7 based on genomic and bibliomic data. Biomed. Res. Int. 2016. [CrossRef] [PubMed]

14. Dall'Agnol, H.P.M.B.; Baraúna, R.A.; de Sá, P.H.C.G.; Ramos, R.T.J.; Nóbrega, F.; Nunes, C.I.P.; Graças, D.A.; Carneiro, A.R.; Santos, D.M.; Pimenta, A.M.C.; et al. Omics profiles used to evaluate the gene expression of Exiguobacterium antarcticum B7 during cold adaptation. BMC Genom. 2014, 15, 986. [CrossRef] [PubMed]

15. Russell, N.J. Mechanisms of thermal adaptation in bacteria: Blueprints for survival. Trends Biochem. Sci. 1984, 9, 108-112. [CrossRef]

16. Sinensky, M. Homeoviscous adaptation a homeostatic process that regulates the viscosity of membrane lipids in Escherichia coli. Proc. Nat. Acad. Sci. USA 1974, 71, 522-525. [CrossRef] [PubMed]

17. Zhang, Y.M.; Rock, C.O. Membrane lipid homeostasis in bacteria. Nat. Rev. Microbiol. 2008, 6, $222-233$. [CrossRef] [PubMed]

18. Aguilar, P.S.; Cronan, J.E.; de Mendoza, D. A Bacillus subtilis gene induced by cold shock encodes a membrane phospholipid desaturase. J. Bacteriol. 1998, 180, 2194-2200. [PubMed]

19. Albnesi, D.; Mansilla, M.C.; de Mendoza, D. The membrane fluidity sensor DesK of Bacillus subtilis controls the signal decay of its cognate response regulator. J. Bacteriol. 2004, 186, 2655-2663. [CrossRef]

20. Aguilar, P.S.; Hernandez-Arriaga, A.M.; Cybulski, L.E.; Erazo, A.C.; de Mendoza, D. Molecular basis of thermosensing: A two-component signal transduction thermometer in Bacillus subtilis. EMBO J. 2001, 20, 1681-1691. [CrossRef] [PubMed]

21. De Mendoza, D. Temperature sensing by membranes. Annu. Rev. Microbiol. 2014, 68, 101-116. [CrossRef] [PubMed]

22. Methé, B.A.; Nelson, K.E.; Deming, J.W.; Momen, B.; Melamud, E.; Zhang, X.; Moult, J.; Madupu, R.; Nelson, W.C.; Dodson, R.J.; et al. The psychrophilic lifestyle as revealed by the genome sequence of Colwellia psychrerythraea 34H through genomic and proteomic analyses. Proc. Nat. Acad. Sci. USA 2005, 102, 10913-10918. [CrossRef] [PubMed]

23. Nunn, B.L.; Slattery, K.V.; Cameron, K.A.; Schiffman, E.T.; Junge, K. Proteomics of Colwellia psychrerythraea at subzero temperatures-A life with limited movement, flexible membranes and vital DNA repair. Environ. Microbiol. 2015, 17, 2319-2335. [CrossRef] [PubMed] 
24. Yoshida, K.; Hashimoto, M.; Hori, R.; Adachi, T.; Okuyama, H.; Orikasa, Y.; Nagamine, T.; Shimizu, S.; Ueno, A.; Morita, N. Bacterial long-chain polyunsaturated fatty acids: Their biosynthetic genes, functions and practical use. Mar. Drugs 2016, 14, 94. [CrossRef] [PubMed]

25. Ting, L.; Williams, T.J.; Cowley, M.J.; Lauro, F.M.; Guilhaus, M.; Raftery, M.J.; Cavicchioli, R. Cold adaptation in the marine bacterium, Sphingopyxis alaskensis, assessed using quantitative proteomics. Environ. Microbiol. 2010, 12, 2658-2676. [CrossRef] [PubMed]

26. Bergholz, P.W.; Bakermans, C.; Tiedje, J.M. Psychrobacter arcticus 273-4 uses resource efficiency and molecular motion adaptations for subzero temperature growth. J. Bacteriol. 2009, 191, 2340-2352. [CrossRef] [PubMed]

27. Mykytczuk, N.C.S.; Foote, S.J.; Omelon, C.R.; Southam, G.; Greer, C.W.; Whyte, L.G. Bacterial growth at $-15{ }^{\circ} \mathrm{C}$; molecular insights from the permafrost bacterium Planococcus halocryophilus Or1. ISME J. 2013, 7, 1211-1226. [CrossRef] [PubMed]

28. Durack, J.; Ross, T.; Bowman, J.P. Characterisation of the transcriptomes of genetically diverse Listeria monocytogenes exposed to hyperosmotic and low temperature conditions reveal global stress-adaptation mechanisms. PLoS ONE 2013, 8, e73603. [CrossRef] [PubMed]

29. Sandermann, H., Jr. Regulation of membrane enzymes by lipids. Biochim. Biophys. Acta 1978, 515, $209-237$. [CrossRef]

30. Kovacic, F.; Mandrysch, A.; Poojari, C.; Strodel, B.; Jaeger, K.E. Structural features determining thermal adaptation of esterases. Protein Eng. Des. Sel. 2016, 29, 65-76. [CrossRef] [PubMed]

31. Feller, G. Psychrophilic enzymes: From folding to function and biotechnology. Scientifica 2013. [CrossRef] [PubMed]

32. Siddiqui, K.S.; Cavicchioli, R. Cold-adapted enzymes. Annu. Rev. Biochem. 2006, 75, 403-433. [CrossRef] [PubMed]

33. Marx, J.C.; Collins, T.; D'Amico, S.; Feller, G.; Gerday, C. Cold-adapted enzymes from marine Antarctic microorganisms. Mar. Biotechnol. 2007, 9, 293-304. [CrossRef] [PubMed]

34. Linding, R.; Jensen, L.J.; Diella, F.; Bork, P.; Gibson, T.J.; Russell, R.B. Protein disorder prediction: Implications for structural proteomics. Structure 2003, 11, 1453-1459. [CrossRef] [PubMed]

35. Ayala-del-Río, H.L.; Chain, P.S.; Grzymski, J.J.; Ponder, M.A.; Ivanova, N.; Bergholz, P.W.; Di Bartolo, G.; Hauser, L.; Land, M.; Bakermans, C.; et al. The genome sequence of Psychrobacter arcticus 273-4, a psychroactive Siberian permafrost bacterium, reveals mechanisms for adaptation to low-temperature growth. Appl. Environ. Microbiol. 2010, 76, 2304-2312. [CrossRef] [PubMed]

36. Yang, G.; Yang, G.; Aprile, L.; Turturo, V.; Pucciarelli, S.; Pucciarelli, S.; Miceli, C. Characterization and comparative analysis of psychrophilic and mesophilic alpha-amilases from Euplotes species: A contribution to the understanding of enzyme thermal adaptation. Biochem. Biophys. Res. Commun. 2013, 4, 715-720. [CrossRef] [PubMed]

37. Thorvaldsen, S.; Hjerde, E.; Fenton, C.; Willassen, N.P. Molecular characterization of cold adaptation based on ortholog protein sequences from Vibrionaceae species. Extremophiles 2007, 11, 719-732. [CrossRef] [PubMed]

38. Fields, P.A. Review: Protein function at thermal extremes: Balancing stability and flexibility. Comp. Biochem. Phys. A 2001, 129, 417-431. [CrossRef]

39. Adekoya, O.A.; Helland, R.; Willassen, N.P.; Sylte, I. Comparative sequence and structure analysis reveal features of cold adaptation of an enzyme in the thermolysin family. Proteins Struct. Funct. Bioinform. 2006, 62, 435-449. [CrossRef] [PubMed]

40. Panoff, J.M.; Corroler, D.; Thammavongs, B.; Boutibonnes, P. Differentiation between cold shock and cold acclimation proteins in a mesophilic gram-positive bacterium, Enterococcus faecalis JH2-2. J. Bacteriol. 1997, 179, 4451-4454. [CrossRef] [PubMed]

41. Phadtare, S. Recent developments in bacterial cold-shock response. Curr. Issues Mol. Biol. 2004, 6, 125-136. [PubMed]

42. Graumann, P.L.; Marahiel, M.A. A superfamily of proteins that contain the cold-shock domain. Trends Biochem. Sci. 1998, 23, 286-290. [CrossRef]

43. Pierce, A.; Gillette, D.; Jones, P.G. Escherichia coli cold shock proteins CsdA effects an increase in septation and the resultant formation of coccobacilli at low temperatures. Arch. Microbiol. 2011, 193, 373-384. [CrossRef] [PubMed]

44. Xia, B.; Ke, H.; Shinde, U.; Inouye, M. The role of RbfA in 16S rRNA processing and cell growth at low temperature in Escherichia coli. J. Mol. Biol. 2003, 332, 575-584. [CrossRef] 
45. Yamanaka, K.; Inouye, M. Selective mRNA degradation by polynucleotide phosphorylase in cold shock adaptation in Escherichia coli. J. Bacteriol. 2001, 183, 2808-2816. [CrossRef] [PubMed]

46. Keto-Timonen, R.; Hietala, N.; Palonen, E.; Hakakorpi, A.; Lindström, M.; Korkeala, H. Cold shock proteins: A minireview with special emphasis on Csp-family of Enteropathogenic Yersinia. Front. Microbiol. 2016, 7, 1151. [CrossRef] [PubMed]

47. Kushwaha, K.; Saxena, J.; Tripathi, B.K.; Agarwal, M.K. Detection of carotenoids in psychrotrophic bacteria by spectroscopic approach. J. BioSci. Biotechnol. 2014, 3, 253-260.

48. Takano, H.; Asker, D.; Beppu, T.; Ueda, K. Genetic control for light-induced carotenoid production in non-phototrophic bacteria. J. Ind. Microbiol. Biotechnol. 2006, 33, 88-93. [CrossRef] [PubMed]

49. Dsouza, M.; Taylor, M.W.; Turner, S.J.; Aislabie, J. Genomic and phenotypic insights into the ecology of Arthrobacter from Antarctic soils. BMC Genom. 2015, 16, 36. [CrossRef] [PubMed]

50. Jagannadham, M.V.; Chattopadhyay, M.K.; Subbalakshmi, C.; Vairamani, M.; Narayanan, K.; Rao, C.M.; Shivaji, S. Carotenoids of an Antarctic psychrotolerant bacterium, Sphingobacterium antarcticus, and a mesophilic bacterium, Sphingobacterium multivorum. Arch. Microbiol. 2000, 173, 418-424. [CrossRef] [PubMed]

51. Dieser, M.; Greenwood, M.; Foreman, C.M. Carotenoid pigmentation in Antarctic heterotrophic bacteria as a strategy to withstand environmental stresses. Arct. Antarct. Alp. Res. 2010, 42, 396-405. [CrossRef]

52. Fong, N.J.C.; Burgess, M.L.; Barrow, K.D.; Glenn, D.R. Carotenoid accumulation in the psychrotrophic bacterium Arthrobacter agilis in response to thermal and salt stress. Appl. Microbiol. Biotechnol. 2001, 56, 750-756. [CrossRef] [PubMed]

53. Chattopadhyay, M.K.; Jagannadham, M.V.; Vairamani, M.; Shivaji, S. Carotenoid pigments of an Antarctic psychrotrophic bacterium Micrococcus roseus: Temperature dependent biosynthesis, structure, and interaction with synthetic membranes. Biochem. Biophys. Res. Commun. 1997, 239, 85-90. [CrossRef] [PubMed]

54. Nupur, L.N.U.; Vats, A.; Dhanda, S.K.; Raghava, G.P.S.; Pinnaka, A.K.; Kumar, A. ProCarDB: A database of bacterial carotenoids. BMC Microbiol. 2016, 16, 96. [CrossRef] [PubMed]

55. Ghobakhlou, A.F.; Johnston, A.; Harris, L.; Antoun, H.; Laberge, S. Microarray transcriptional profiling of Arctic Mesorhizobium strain N33 at low temperature provides insights into cold adaption strategies. BMC Genom. 2015, 16, 383. [CrossRef] [PubMed]

56. Palsson, B. In silico biology through “omics". Nat. Biotechnol. 2002, 20, 649-650. [CrossRef] [PubMed]

57. Hashimoto, T.; de Hoon, M.J.L.; Grimmond, S.M.; Daub, C.O.; Hayashizaki, Y.; Faulkner, G.J. Probabilistic resolution of multi-mapping reads in massively parallel sequencing data using MuMRescueLite. Bioinformatics 2009, 25, 2613-2614. [CrossRef] [PubMed]

58. Petrak, J.; Ivanek, R.; Toman, O.; Cmejla, R.; Cmejlova, J.; Vyoral, D.; Zivny, J.; Vulpe, C.D. Déjà vu in proteomics: A hit parade of repeatedly identified differentially expressed proteins. Proteomics 2008, 8 , 1744-1749. [CrossRef] [PubMed]

59. Williams, T.J.; Wilkins, D.; Long, E.; Evans, F.; DeMaere, M.Z.; Raftery, M.J.; Cavicchioli, R. The role of planktonic Flavobacteria in processing algal organic matter in coastal East Antarctica revealed using metagenomics and metaproteomics. Environ. Microbiol. 2013, 15, 1302-1317. [CrossRef] [PubMed]

60. Karlson, C.; Malmström, L.; Aebersold, R.; Malmström, J. Proteome-wide selected reaction monitoring assays for the human pathogen Streptococcus pyogenes. Nat. Commun. 2012, 3. [CrossRef] [PubMed]

61. Olaya-Abril, A.; Jiménez-Munguía, I.; Gómez-Gascón, L.; Rodríguez-Ortega, M.J. Surfomics: Shaving live organisms for a fast proteomic identification of surface proteins. J. Proteom. 2014, 97, 164-176. [CrossRef] [PubMed]

(C) 2017 by the authors. Licensee MDPI, Basel, Switzerland. This article is an open access article distributed under the terms and conditions of the Creative Commons Attribution (CC BY) license (http:/ / creativecommons.org/licenses/by/4.0/). 